\title{
Establishment and traffic stress response of tall fescue as affected by Mycorrhiza fungi and Trinexapac-ethyl
}

\author{
Alireza Jabbari ${ }^{1}$, Iman Rohollahi ${ }^{{ }^{*}}$
}

\begin{abstract}
Heavy traffic regularly causes damage of substantial aboveground parts to turf grasses. Several factors could affect the traffic stress severity, including the number of occasions per season and the soil moisture content during the traffic stress. Mycorrhiza results in numerous advantages to host plant like improving the turfgrass establishment, root structure and also abiotic stress tolerance of plants. Festuca arundinacea remains green during the playing season and it is the most popular turf grass for football. Trinexapacethyl (TE) might be influence the wear as growth retardant. Accordingly, mycorrhiza infection effect on tall fescue establishment, and TE effect on traffic stress after establishment were studied. The treatments, including traffic stress (traffic and non-traffic

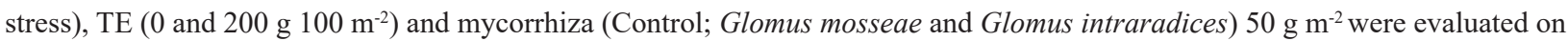
two cultivars of tall fescue in two growing season of 2017 and 2018. Both mycorrhizas were significantly colonized on turfgrass root during establishment. G. intraradices inoculation increased the establishment by passing 60 days from seeding in $F$. arundinacea cv. Barvado. After establishment, traffic stress reduced the relative water content (RWC) in 2017 and 2018, and also reduced the turf quality and soluble sugar content (SSC). TE improved the RWC, SSC, turf quality and also colonization percentage. Mycorrhiza inoculation enhanced tall fescue establishment. TE application at $200 \mathrm{~g} 100 \mathrm{~m}^{-2}$ had no influence on traffic stress, however, it improved turf quality, RWC, SSC and mycorrhiza colonization.
\end{abstract}

Keywords: Colonization, Festuca, plant growth regulator, turf quality, wear tolerance

\section{Introduction}

Turf foot traffic is the main culprit on sport field. Foot traffic stress, particularly on wet soil, can also result in injury to the turfgrass crown and the root structure upper area (Christians et al., 2004). Turfgrass wear tolerance can be increased applying several methods. Higher weartolerance cool-season turfgrass genus selecting (Trappe et al., 2009) and also plant growth retardants application are two important methods for eliminating traffic stress (Mohamadi et al., 2017).

Festuca arundinacea as an important adapted cold, arid and semiarid environments grass species (Christians et al., 2004) are indicating good wear tolerance amongst cool-season species (Harivandi, 2002). On the other hand, former experiment has not evaluated different Festuca arundinacea responses that were inoculated with mycorrhiza under traffic stress.

Mycorrhiza inoculation is an opportunity, which can be beneficial for turf grass establishment (Pelletier and Dionne, 2004) and also root structure. Mycorrhiza bring several profits to host Festuca (Molina et al., 2008) like plant growth and tolerance to abiotic stress. Trinexapac-ethyl (TE) is a popular plant growth substances (Gibberellic acid inhibitor) in the turf grass industry and could efficiently increase the chlorophyll content and turf quality (Roohollahi and Kafi, 2010), however, it reduces the leaf elongation and clipping production (Ervin and Koski, 2001). Hereafter, TE can enhance both drought (Roohollahi et al., 2010) and wear tolerance (Mohamadi et al., 2017). Moreover, TE increased the quality of turf and wear tolerance of bermudagrass under simulated traffic stress (Williams et al., 2010). In addition, Feng et al. (2002) stated that TE could increase the rate of mycorrhizal infection and hyphal colonization in Agrostis palustris Huds. Therefore, Trinexapac-ethyl (TE) and mycorrhiza inoculation simultaneous effect on traffic stress is still undetermined. This study purpose was to determine mycorrhiza infection effect on Festuca arundinacea establishment, and also discuss about TE influence on traffic stress after mycorrhiza inoculation. This study also evaluated the turf quality during the establishment and simulated traffic stress using digital image analysis (DIA).

\footnotetext{
${ }^{1}$ Shahed University, Department of Horticulture Science,Tehran, IRAN. "Corresponding author: i.rohollahi@shahed.ac.ir
} 


\section{Materials and Methods}

The first experiment was accomplished on a sandyloamy soil ( $70 \%$ sand, $18.5 \%$ silt, $11.5 \%$ clay) at Shahed university, Tehran province, $\operatorname{Iran}\left(35^{\circ} 33^{\prime} 14^{\prime \prime} \mathrm{N} 51^{\circ} 20^{\prime}\right.$ 26.3 “E), in the autumn of 2017 (Table 1). Experimental plots were measured as $1.5 \times 1.5 \mathrm{~m}$ and were also separated from each other by $50 \mathrm{~cm}$ paths. There were three mycorrhiza treatments: Glomus mosseae and Glomus intraradices at $50 \mathrm{~g} \mathrm{~m}^{-2}$ in the form of a mixture of spores (30 - 40 spores per gram), soil, and infected maize (Zea may L.) roots and uninoculated control. On 15 April 2017, plots were inoculated using mycorrhiza fungi supplied as spores in a sand and plant roots mixture that were prepared from Turan biotech Co, Shahrood, Iran. Also, this mycorrhiza mixture is commercially available. At the same time, plots were seeded by the use of a Festuca arundinacea L. cv. Barvado and Asterix (Barenbrug Holland B.V.). Both mycorrhiza inoculum and seed were sprinkled by hand over the surface plots consistently, and were also mixed with a rake and top covered with $1 \mathrm{~cm}$ of the manure. Turf plots were not fertilized and also not treated with pesticides at the time of the establishment. Also, weeds were manually removed every day and plots were not mowed during the establishment period.

Table 1. Average temperature during the experiments

\begin{tabular}{|c|c|c|c|c|c|c|}
\hline Month & April & May & June & October & November & December \\
\hline Average Temperature $\left({ }^{\circ} \mathrm{C}\right)$ & 27 & 21.5 & 12 & 25.5 & 29 & 31 \\
\hline
\end{tabular}

Field was arranged in factorial experiment with respect to completely randomized block design, along with three replications. Plot area percentage that was covered by turf grass was evaluated 15 times using DIA (Richardson et al., 2001) in 60 days from 20 April to 20 June 2017. Shoot height was evaluated in cm every week for two months by passing two weeks from appearing the first germination sign. Vertical shoot height was evaluated by measuring the difference in average canopy height with a ruler. The ruler was placed in three different areas of the canopy. In order to assess mycorrhiza colonization, root were stained (Phillips and Hayman, 1970) and mycorrhiza colonization percentage was assessed on 100 root intersections using the gridline intersect method of introduced by Giovannetti and Mosse (1980). In the next step, the shoots were dried at $105{ }^{\circ} \mathrm{C}$. The total phosphorus concentration of plants was evaluated by the use of colorimetric technique (Cavell, 1955).

Second experiment was accomplished during two growing seasons (2017 and 2018); on the same plots that the first experiment cultivation was performed. The plots were irrigated ( $\mathrm{pH} 7$, electrical conductivity $0.5 \mathrm{mS} \mathrm{cm}^{-1}$ ) in order to keep the soil moisture content at $75 \%$ field capacity or higher in that two-month duration of establishment. All plots were mowed using reel-type mower one day before TE application, and were maintained at $4 \mathrm{~cm}$ cutting height. TE (Primo Maxx; Syngenta Crop Protection, Inc.,

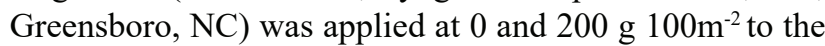
plots, respectively. The TE was sprayed using a backpack sprayer (30 psi). The spray solution was utilized at $0.3 \mathrm{~L} \mathrm{~m}$ ${ }^{-2}$ a volume. Afterward, control plots were sprayed with 0.3 $\mathrm{L} \mathrm{m}^{-2}$ distilled water.

Traffic stress was simulated by the use of a Brinkman traffic simulator (BTS) (Cockerham and Brinkman, 1989). Traffic treatments were imposed every Sunday, Tuesday and Thursday with two passes is approximately equivalent to those injuries as a result of three American football games per week (Williams et al., 2010). Leaf samples were gathered from each plot on days 4, 8, 16 and days 1, 6, 12, 24 in the first and second experiment, respectively, in order to determine their relative water content (RWC) (Barrs and Weatherley, 1962), chlorophyll concentration (Arnon, 1949), soluble sugar content (SSC) (Buysse and Merckx, 1993), proline content, total protein (Bradford, 1976), catalase (CAT) and peroxidase (POD) activity (Chance and Maehly, 2004), mycorrhiza colonization and phosphorus concentration. Clipping were dried in oven at $60{ }^{\circ} \mathrm{C}$, and clipping dry weights were evaluated for each plot-sampling zone. In addition, canopy height was assessed every week after treatment, and turf quality was computed using DIA. The DIA process included, obtaining an image with digital photography and calculating RGB (The amount of Red, Green and Blue light emitted for each pixel in the image) using Sigma Scan Pro version 5.0 software (SPSS, 1998). Analysis of variance was accomplished with respect to the statistical analysis system (SAS Institute, Cary, N. C.) mixed model. Also, data separately analyzed separately for each experiment. Significance probabilities amongst treatments were applied in order compare means between treatments. The comparison of means was done by Duncan's multiple range test.

\section{Results}

\section{First experiment}

Turfgrass establishment and Mycorrhizal colonization

$F$. arundinacea cv. Barvado and $F$. arundinacea cv. Asterix germinated by passing 22 days and 18 days from seeding in all treatments, respectively, as a result, mycorrhiza indicated to have no effect on germination rate (Figure 1A and 1B). F. arundinacea cv. Barvado inoculated with $G$. intaradices were extensively established in comparison with $G$. mosseae 60 days from infection (Figure 1A). Plots infected with $G$. intaradices had an average of 
$62 \%$ and $71 \%$, while they had average of $54 \%$ and $62 \%$ turf grass coverage with $G$. mosseae, by passing 50 and 60 days from inoculation, respectively. F. arundinacea cv. Barvado coverage increased to an average of $74 \%$ with using both mycorrhiza treatment by passing 70 days from seeding (Figure 1A). F. arundinacea cv. Asterix that were inoculated with both mycorrhiza treatments had an average of $70 \%$ coverage by passing 60 days from seeding (Figure 1B). There exists meaningful and significant difference in the root mycorrhizal colonization rate (Figure 1C). By passing two months from mycorrhizal infection, the average root colonization increased to $32 \%$ (Figure 1C).



Days after planting and inoculation

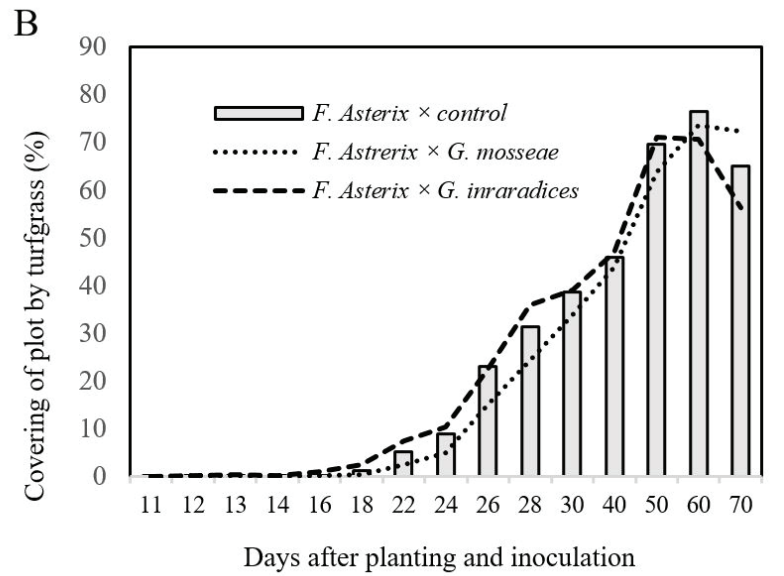



Figure 1. Plot coverage by turf grass in F. arundinacea cv. Barvado (A), Plot coverage by turf grass in F. arundinacea cv. Asterix (B) and Colonization percentage

\section{Second experiment}

After the TE and traffic stress application in the fourth day in 2017 and the first day in 2018, the RWC of all treatments has significantly changed as shown in Figure $2 \mathrm{~A}$ and Figure 2B, respectively. Traffic stress eliminated the RWC, however TE application substantially increased leaf RWC in 2017 and 2018 (Figure 2A and 2B). Also, it is noteworthy to state that TE under traffic stress had no positive influence (Figure 2A and 2B). 


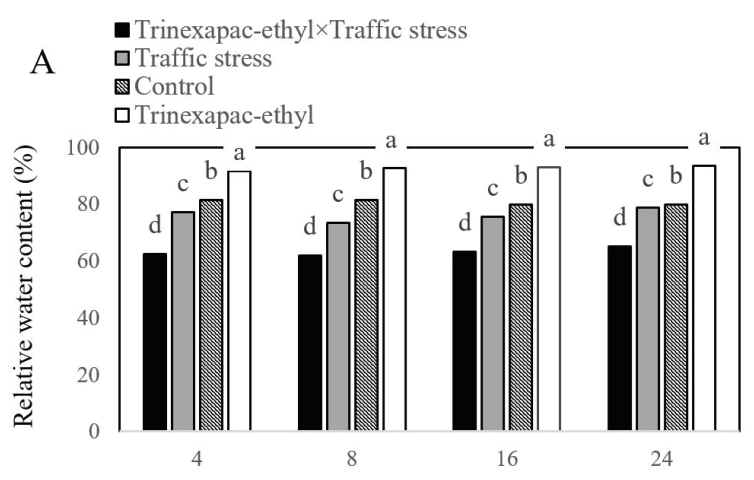

Days after treatments - 2017
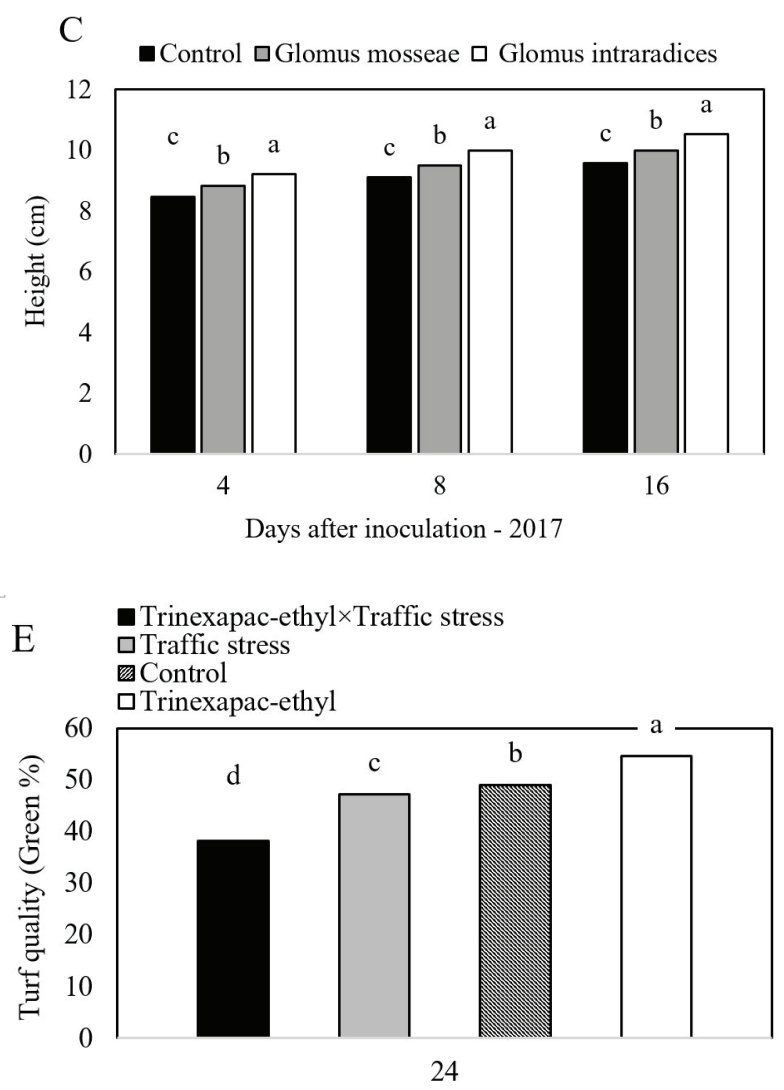

Days after treatments - 2017

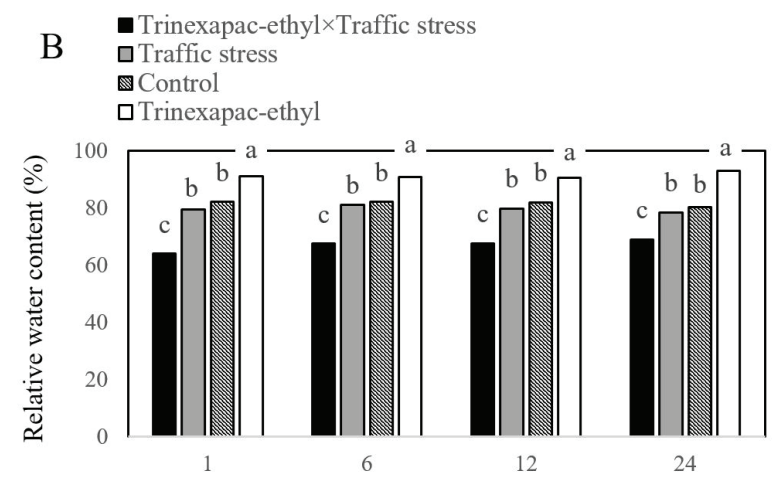

Days after treatments - 2018
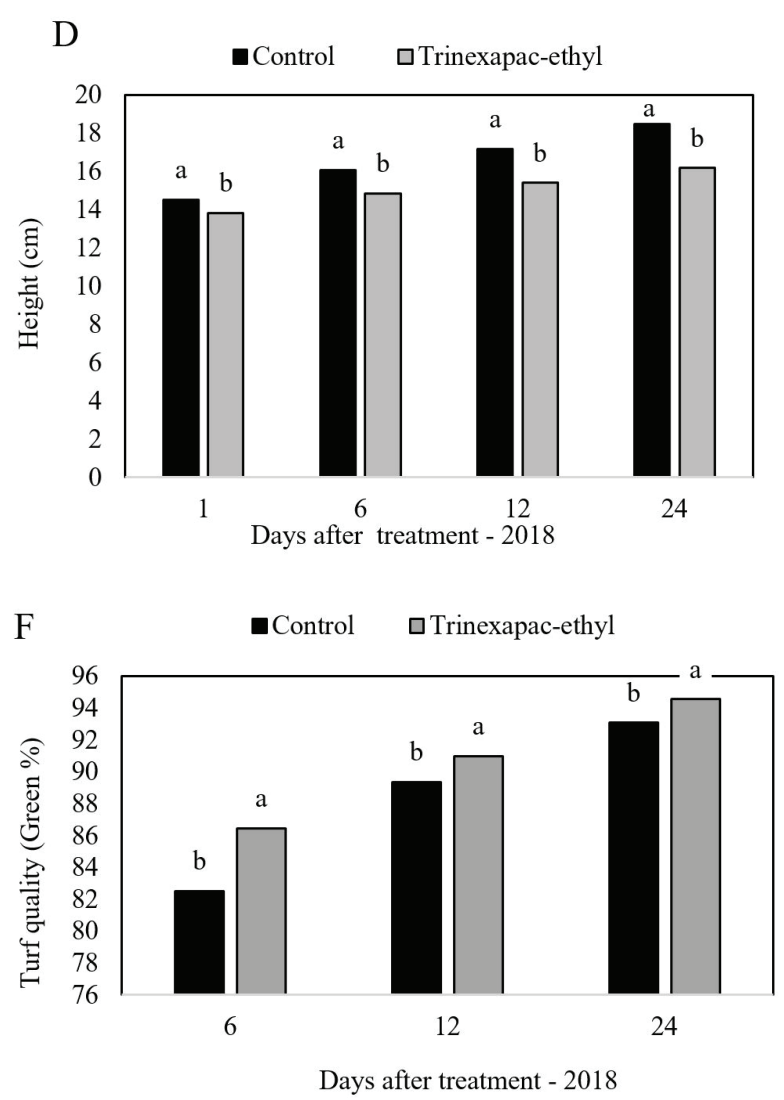

Figure 2. Changes in relative water content (RWC) 2017 (A) and relative water content (RWC) 2018 (B) under Trinexapac-ethyl and traffic stress. Canopy height 2017 after inoculation with Glomus mosseae, Glomus intraradices and control (C), Canopy height 2018 under Trinexapac-ethyl treatment (D), Turf quality percentage under Trinexapacethyl and traffic stress (E), Turf quality percentage under Trinexapac-ethyl treatment (F). Values sharing a common letter are not significantly different at $\mathrm{p}<0.05$.

G. intaradices significantly increased the canopy height in 2017 (Figure 2C), and TE considerably decreased the canopy height until the 24th day after treatments, in comparison with control plant in 2018 (Figure 2D).

Traffic stress reduced the turf quality of turf, also interaction between TE and Traffic stress has significantly decreased the turf quality in 2017 (Figure 2E). Moreover, TE enhanced the quality of turf quality in 2017, and also increased it in 2018 until 24 day after treatments (Figure 2F).

With respect to this study, TE application (200 g $100 \mathrm{~m}^{-2}$ ) increased the SSC content under traffic stress in 2017 (Figure 3A). TE application also significantly decreased the catalase activity in 2017 (Figure 3B) and 2018 (Figure 3C) respectively, also peroxidase activity considerably decreased in 2018 under TE treatment (200 g $100 \mathrm{~m}^{-2}$ ) (Figure 3D). In addition, chlorophyll content remarkably increased in $F$. arundinacea cv. Barvado under TE application in 2018 (data were not displayed). $G$. intaradices in F. arundinacea cv. Barvado and G. mosseae in $F$. arundinacea $\mathrm{cv}$. Astrerix significantly increased the protein concentration significantly increased by (data were not displayed). 

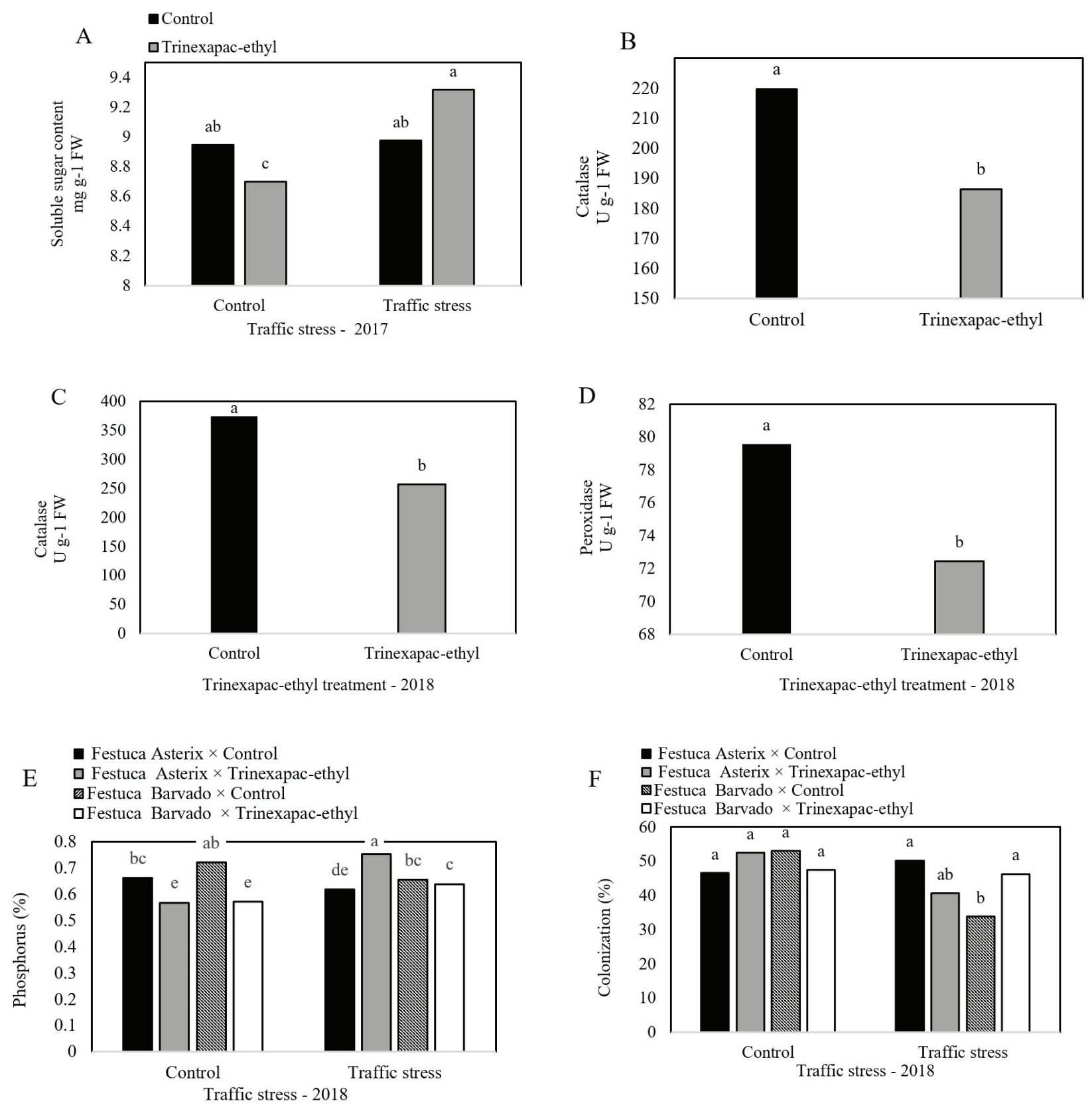

Figure 3. Soluble sugar content under Trinexapac-ethyl and traffic stress 2017 (A), Catalase activity under Trinexapac-ethyl treatment 2017 (B) and 2018 (C), Peroxidase activity under Trinexapac-ethyl treatment 2018 (D), Phosphorus concentration under Trinexapac-ethyl and traffic stress treatments in Festuca arundinacea cv. Barvado and Asterix 2018 (E), Colonization percentage under Trinexapac-ethyl and traffic stress treatments in Festuca arundinacea cv. Barvado and Asterix 2018 (F). Values sharing a common letter are not significantly different at $p<0.05$.

Phosphorus concentration reduced by applying TE application on both $F$. arundinacea cultivars under unstressed condition (Figure 3E) whereas, TE remarkably increased the $F$. arundinacea cv. Asterix phosphorus concentration under traffic stress condition in 2018 (Figure $3 \mathrm{~F}$ ). TE treatment did not change the $F$. arundinacea colonization percentage under non-traffic stress condition, while TE increased the colonization percentage (27\%) with F. arundinacea cv. Barvado under traffic stress in 2018.

\section{Discussion}

This study purpose was to determine the rate of tall fescue establishment after mycorrhiza inoculation in the 
first experiment, on the other hand, effect of applying TE on two cultivars of $F$. arundinacea after establishment and mycorrhiza infection was evaluated under traffic stress in second experiment. This study indicated that the seed inoculation with mycorrhiza have the ability of colonizing the $F$. arundinaceae seeding roots, and also increasing the colonization percentage during the establishment period. $G$. intaradices infection indicated a greater percentage of $F$. arundinaceae cv. Barvado establishment in comparison with the $G$. mosseae inoculation (Figure 1A). This proposes that $G$. intaradices is more effective in increasing the speed of turf grass coverage percentage compared to G. mosseae. Pelletier and Dionne (2004) reported such differences between $G$. intaradices and $G$. etunicatum that were consistent with this study results. They concluded that $G$. intaradices is more effective at the rates between 40 and $60 \mathrm{~g} \mathrm{~m}^{-2}$ in comparison with $G$. etunicatum in enhancing the mixture of Kentucky bluegrass (Poa pratensis L.), red fescue (Festuca rubra L.) and perennial ryegrass (Lolium perenne L.) establishment rate, at the time of inoculation during seeding.

Wear injury would damage turf grass canopy parts (crowns, leave and stem) by physical compaction and abrasion that may decrease RWC (Christians et al., 2004). Also, Ervin and Koski (2001) and Mohamadi et al. (2017) indicated that traffic stress condition decreased RWC, however, TE treatment increased RWC along with evapotranspiration rate and leaf growth rate decreasing, and all of these are consistent with this study results. Although, other studies found that applying TE significantly increased the leaf RWC under traffic stress (Mohamadi et al., 2017), but our results demonstrated that RWC significantly decreased under TE

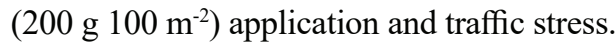

Roohollahi and et al. (2010) indicated canopy height reduction through 4 weeks after treatments that are in agreement with this study results. Canopy height reduction under TE application was reported by many researchers (Fagerness and Penner, 1998; Ervin and Koski, 2001). TE could also reduce cell elongation and height as results of GA biosynthesis inhibition. Also, this study results indicated reduction in canopy height by passing 24 days from treatments by TE in 2018 (Figure 1B).

Samaranayake et al., (2008) indicated that traffic stress diminished the turf grass quality of Agrostis stolonifera L. in this study, similar to Ervin and Koski, (2001) positive effects of TE on the turf quality has been reported. Improving Turf quality by applying TE might lead to the cell density and chlorophyll-b concentration increasing, while reducing cell length (Ervin and Koski, 2001; Roohollahi et al., 2010). TE was not absorbed after high traffic stress and interaction between TE and Traffic stress considerably diminished the turf quality in 2017, because of high traffic stress and crown compaction (Figure 2E). Therefore, this study findings do not support the controversial claims in the study accomplished by Mohamadi et al., (2017). Fagerness and Penner (1998) claimed that the plant base (crown) being the greater site of absorption for TE, on the other hand traffic stress injures crowns by compressing which in turn may result in TE absorption loss. Also, in this study, traffic stress was imposed every Sunday, Tuesday and Thursday by two passes per day, respectively, that was twice under the traffic stress in investigations (Mohamadi et al., 2017). Mohamadi et al., (2017) also considered TE at three levels $\left(0,0.25\right.$ and $\left.0.5 \mathrm{~kg} \mathrm{ha}^{-1}\right)$ whereas TE concentration was 200 $\mathrm{g} 100 \mathrm{~m}^{-2}$ in our investigation.

Khoshkholghsima and Rohollahi, (2015), concluded $\mathrm{SSC}$ and $\mathrm{H}_{2} \mathrm{O}_{2}$ content increased in perennial grasses under drought stress condition, and it was associated with plant ability in stress tolerating. SSC content improved by TE $0.5 \mathrm{~kg} \mathrm{ha}^{-1}$ in tall fescue by passing 42 and 63 days from treatment under traffic stress (Mohamadi et al., 2017). They indicated that traffic stress could reduce the POD activity, also reducing the CAT activity in wheatgrass by passing 21 and 42 days from TE $\left(0.25 \mathrm{k} \mathrm{ha}^{-1}\right)$ application under traffic stress (Mohamadi et al., 2017). TE increased the Poa pratensis tolerance against salinity stress by increasing the enzymes CAT, POX and SOD activity (Arghavani et al., 2012). Antioxidative enzymes activity and ROS balance describes whether oxidative signaling or damage will occurred in selected cultivar or not (Rohollahi et al., 2018). TE could increase $(27 \%)$ the colonization under traffic stress condition (Figure 3F). Greater mycorrhiza infection by hyphal colonization in TE treated plants were also reported by (Feng et al., 2002).

\section{Conclusions}

This study results lead us to the concluding that TE application was beneficial for establishing tall fescue under mycorrhiza inoculation, also efficient mycorrhiza species should be carefully selected before inoculating. This study finding indicated that $50 \mathrm{~g} \mathrm{~m}^{-2} \mathrm{G}$. intaradices is an optimal inoculation rate during establishment of Festuca arundinacea. We can conclude that, the TE application at

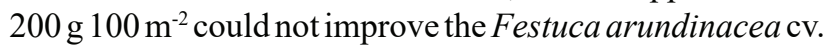
Bravado and Asterix wear tolerance, whereas TE improved the turf quality, RWC, SSC content and also colonization percentage under traffic stress. TE decreased the activity of CAT and POD activity in F. arundinacea cv. Bravado and Asterix, which indicates the equilibrium between antioxidative enzymes and ROS production activities. TE application increased the colonization percentage of mycorrhiza, whereas $G$. intaradices increased height and establishment of tall fescue canopy.

\section{Author Contribution}

$$
\text { A.J. }{ }^{0000-0003-4623-5385} \text { and I.R. }{ }^{0000-0002-6230-1568} \text { : worked together }
$$
in all research steps, such as planting, treatments and managing turfgrass plots, data collection, analysis and interpretation, preparation and review of the manuscript.

\section{Acknowledgements}

The authors are thankful to the Dr. Amir Mohammad Naji for design of the research and analyze of data. 


\section{References}

ARGHAVANI, M.; KAFI, M.; BABALAR, M.; NADERI, R.; HOQUE, M.A.; MURATA, Y. Improvement of salt tolerance in Kentucky bluegrass by Trinexapac-ethyl. HortScience, v.47, p.1163-1170, 2012. DOI: https://doi. org/ 10.21273/HORTSCI.47.60.1163

ARNON, D.I. Copper enzymes in isolated chloroplasts polyphenol oxidase in Beta vulgaris. Plant physiology, v.24, p.1-15, 1949. DOI: https://doi.org/10.1104/ p.p. 24.1.

BARRS, H.D.; WEA, P.E. A re-examination of the relative turgidity technique for estimating water deficits in leaves. Australian Journal of Biological Science. v.15, n.3, p.413-428, 1962. DOI: https://doi.org/10.1071/ BI9620413.

BRADFORD, M.M. A rapid and sensitive method for the quantitation of microgram quantities of protein utilizing the principle of protein-dye binding. Analytical Biochemistry, v.72, p.248-54, 1976. DOI: https://doi.org/10.1016/00032697(76)90527-3.

BUYSSE, J.; MERCKX, R. An Improved colorimetric method to quantify sugar content of plant tissue. Journal of Experimental Botany, v.44, p.1627-1629, 1993. DOI: https://doi.org/10.1093/jxb/44.10.1627

CAVELL, A.J. The colorimetric determination of phosphorus in plant materials. Journal of the Science of Food and Agriculture, v.6, p.479-480, 1955. DOI: https:// doi.org/10.1002/jsfa.2740060814

CHANCE, B.; MAEHLY, A.C. Assay of catalases and peroxidases. Methods in Enzymology, v.2, p.764-775, 1955. DOI: https://doi.org/10.1016/S0076-6879(55)023008

CHRISTIANS, N.E; PATTON, A.J; LAW, Q.D. Fundamentals of turfgrass management. John Wiley \& Sons, Hoboken, NJ. 2004. 480 p.

COCKERHAM, S.T.; BRINKMAN, D.J. A simulator for cleated-shoe sports traffic on turfgrass research plots. California Turfgrass Culture, v.39, n.3-4, p.9-10, 1989.

ERVIN, E.H.; KOSKI, A.J. Trinexapac-ethyl increases Kentucky bluegrass leaf cell density and chlorophyll concentration. HortScience, v.36, p.787-789, 2001. DOI: https://doi.org/10.21273/HORTSCI.36.4.787.

FAGERNESS, M.J.; PENNER, D. 14C-Trinexapac-ethyl absorption and translocation in Kentucky bluegrass. Crop Science, v.38, p.1023-1027, 1989. DOI: https://doi. org/10.2135/cropsci1998.0011183X003800040023x.
FENG, Y; STOECKEL, D.M; VAN SANTEN, E; WALKER, R.H. Effects of subsurface aeration and Trinexapac-ethyl application on soil microbial communities in a Creeping bentgrass putting green. Biology and Fertility of Soils, v.36, p.456-460, 2002. DOI: https://doi.org/10.1007/ s00374-002-0558-1.

GIOVANNETTI, M.; MOSSE, B. An evaluation of techniques for measuring vesicular arbuscular mycorrhizal infection in root. New Phytologist, v.84, n.3, p.489-500, 1980.

HARIVANDI, M.A. Turfgrass traffic and compaction: Problems and solutions, turfgrass traffic and compaction: problems and solutions. University of California, agriculture and natural resources. 2002. DOI: https://doi. org/10.3733/ucanr.8080

KHOSHKHOLGHSIMA, N.A.; ROHOLLAHI, I. Evaluating biochemical response of some selected perennial grasses under drought stress in Iran. Horticulture Environment and Biotechnology, v.56, p.383-390, 2015. DOI: https://doi.org/10.1007/s13580-015-0010-8

MOHAMADI, M.H.S., ETEMADI, N.; NIKBAKHT, A.; PESSARAKLI, M. Physiological responses of two coolseason grass species to Trinexapac-ethyl under traffic stress. HortScience. v.52, p.99-109, 2017. DOI: https:// doi.org/10.21273/HORTSCI11228-16

MOLINA, R.J; TRAPPE, J.M; STRICKLER, G.S. Mycorrhizal fungi associated with Festuca in the western United States and Canada. Canadian Journal of Botany, v.56, p.1691-1695, 2008. DOI: https://doi.org/10.1139/ b78-198

PELLETIER, S.; DIONNE, J. Inoculation rate of arbuscular-mycorrhizal fungi Glomus intraradices and Glomus etunicatum affects establishment of landscape turf with no irrigation or fertilizer inputs. Crop Science, v.44, p.335-338. 2004. DOI: https://doi.org/cropsci2004.3350.

PHILLIPS, J.M.; HAYMAN, D.S. Improved procedures for clearing roots and staining parasitic and vesiculararbuscular mycorrhizal fungi for rapid assessment of infection. Transactions of the British Mycological Society, v.55, p.158-IN18, 1970. DOI: https://doi. org/10.1016/S0007-1536(70)80110-3

RICHARDSON, M.D; KARCHER, D.E; PURCELL, L.C. Quantifying turfgrass cover using digital image analysis. Crop Science, v.41, p.1884-1888, 2001. DOI: https://doi. org/10.2135/CROPSCI2001.1884. 
ROHOLLAHI, I; KHOSHKHOLGHSIMA, N.A;
NAGANO, H; HOSHINO, Y; YAMADA, T. Respiratory burst oxidase-D expression and biochemical responses in Festuca arundinacea under drought stress. Crop Science, v.58, p.435-442, 2018. DOI: https://doi.org/10.2135/ cropsci2017.07.0416

ROOHOLLAHI, I.; KAFI, M. Salinity and Trinexapacethyl effects on seed reserve utilization and seedling growth of two Lolium perenne Cultivars. Horticulture Environment and Biotechnology, v.51, p.78-82, 2010

ROOHOLLAHI, I; KAFI, M; NADERI, R. Drought reaction and rooting characteristics in response to plant growth regulators on Poa pratensis cv. Barimpala. Journal of Food Agriculture and Environment, v.8, p.285-288, 2010 .
SAMARANAYAKE, H; LAWSON, T.J; MURPHY, J.A. Traffic stress effects on bent grass putting green and fairway turf. Crop Science, v.48, p.1193-1202, 2008. DOI: https://doi.org/10.2135/cropsci2006.09.0613

SPSS. Sigma Scan Pro 5.0. SPSS Science Marketing Dep., Chicago. 1998.

TRAPPE, J; KARCHER, D; RICHARDSON, M; PATTON, A. Shade and traffic tolerance of bermuda grass and zoysiagrass. Crop Science, v.75, n.2, p.870-877, 2009. DOI: https://doi.org/10.2135/cropsci2010.05.248.

WILLIAMS, D.W; BURRUS, P.B; CROPPER, K.L. Seeded bermudagrass tolerance to simulated athletic field traffic as affected by cultivars and Trinexapac-ethyl. HortTechnology, v.20, p.533-538, 2010. DOI: https://doi. org/10.21273/HORTTECH.20.3.533. 